\title{
构建水系治理长效机制 全面提升毫州水环境建设水平探讨
}

\author{
代文明 \\ 毫州市河道管理局 \\ DOI:10.32629/hwr.v4i4.2930
}

[摘 要] 在全面推进生态文明建设和环境保护大背景下,结合毫州实际情况, 毫州市委、市政府对毫州环境建设提出了“地净、路畅、水活、 天蓝、林拥城”的目标要求, 实施 “水活”工程, 进一步改善毫州市水资源生态环境。但由于毫州市长期存在着未经处理的污水直排、水资源自 净能力减弱等突出问题,因此, 毫州市水利局治理水污染的任务比较艰巨。本文基于毫州市水资源环境现状,为毫州市打赢水污染防治攻坚战,提 出相应的对策建议。

[关键词] 城市水污染; 水污染防治长效机制; 水环境建设

\section{引言}

良好的水资源环境是一个城市的重要文化形象, 代表着一个城市的 文化品位, 体现着一个城市的技术特色, 是直接促进一个城市国民经济 社会发展的重要支撑。因此, 建设和完善城市水资源环境对发掘城市文 化内涵、提高城市环境品位具有重要意义。目前毫州市的水资源环境依 然脆弱, 水资源环境建设体系方面还存在着一些不足。如何全面提升毫 州市水资源环境建设, 建立长期有效的水污染防治机制, 相关部门需要 积极发挥职能作用。

\section{1 毫州市水资源环境建设现状}

1. 1 毫州水资源现状

毫州市位于安徽省西北部, 地处华北平原南端, 距省城合肥 330 公里, 北依河南省商丘市, 西与周口市鹿邑县接壤, 东部与淮北市、蚌埠市相倚, 东南部与淮南市为邻, 面积8374平方公里。毫州市多年的平均降水量为 $827.3 \mathrm{~mm}$, 平均水资源量为 24.88 亿总。按全市常驻人口 523.7 万人计算, 人 均水资源量为 $487 \mathrm{~m}^{3}$, 不及全省人均水资源量 $1100 \mathrm{~m}^{3}$ 的 $1 / 2$, 不及全国人均 水资源量 $2200 \mathrm{~m}^{3}$ 的 $1 / 4$ 。毫州市作为安徽省最重要的粮食主产区, 水资源极 度缺乏, 是安徽省水资源贫乏的干早地区之一。毫州市辖区内流域面积 10 平方公里以上的河道 367 条, 分属淮河水系和洪泽湖水系。主要骨干河流有 浴河、西泪河、茨淮新河、苂河、北淝河等。毫州市境内现有防洪水闸 378

(2) 与项目法人签订移民安置协议, 与乡 (镇) 人民政府签订移民安置 目标责任书。

(3) 与项目法人共同委托移民监督评估单位开展移民综合监理和监测 评估工作。

（4）根据移民安置规划和项目法人的年度移民安置计划建议, 在与项 目法人充分协商的基础上, 组织编制并下达本行政区域的下年度移民安置 年度计划, 按要求上报移民安置实施项目和资金使用统计报表。

（5）负责按照批准的移民安置规划，拨付、使用和管理移民安置资金、 水库移民后期扶持资金; 组织对单项移民工程资金的使用进行审计。

（6）根据移民安置协议, 负责专业项目恢复改建, 并组织竣工验收和移交。

（7）负责处理本行政区域内移民来信来访, 建立健全移民信息公开、参 与、协商、诉求表达等机制, 及时稳妥处理突发事件。

(8) 负责处理本行政区域内库底清理及移民安置验收 (自验)工作。

（9）负责移民信息统计, 建立健全移民工作档案, 并按照国家有关规定 进行管理。

（10）负责组织本行政区域内移民培训和移民干部培训工作。

(11) 配合项目法人办理建设项目临时用地手续、依法办理移民安置区
座, 其中大型防洪水闸有四座: 大寺闸、浴阳闸、蒙城闸、闻疃闸。污水 处理排灌站有 2818 处, 装机 7.0 万 $\mathrm{kw}$, 万亩以上中小灌区 19 处, 万亩以上中 小灌区机井 5.3 万眼。毫州市工业企业和城市生活用水长期依赖中深层和 深层地下水, 人们集中、超强度地开采地下水, 导致地下水水位下降较为明 显。另外, 毫州市部分地区的地下水含氟量超标, 部分地区地下水含铁、锰 量微超标。

\section{2 毫州市 “水活” 工程规划落实情况}

毫州市政府及水利部门根据本地水资源环境建设现状, 提出并实施 《毫州市中心城区水系贯通规划方案》(2015版), 对扩大后的毫州城区水 系进行全面、综合的规划。包括: “一涵四闸” 水系贯通控制工程; 宋汤 河四期工程; 宋汤河五期工程; 宋汤河六期工程; 凤尾沟二期工程; 凤尾 沟三期工程; 龙风新河 (毫苟路一毫芜大道段)工程; 团结沟工程等。

毫州市水利局一直秉持着深化学习、终身持续学习的思想观念, 全面 提升毫州市城区水系贯通治理工作的管理水平。为进一步提高自身的业务 能力, 水利局组织水系项目处及有关工程施工、设计、监理单位分赴六安、 池州等地进行实地考察, 汲取其他城市的水系治理经验。相关部门通过实 地考察、实例研究, 不仅开拓了视野, 找出了与其他城市水系治理之间的差 距, 完善本市原有方案中的不足, 还全面提升了自身水系贯通治理工作的 业务能力和管理水平。

建设用地手续。

3 结语

综上所述, 面对水利工程建设带来的挑战, 应该正确看待水库移民搬 迁安置重要性, 充分契合区域实际情况, 在明确政府角色定位基础上, 制定 各级政府移民安置职责, 坚持以人为本规范化组织管理, 提升组织管理效 率的同时, 切实维护水库移民切身权益。

[参考文献]

[1]胡慧灵.基于农旅融合视角的乡村旅游精准扶贫研究分析一一以 达州市大竹县大中型水库库区及移民安置区为例 [ J]. 农村经济与科 技,2019,30(17):102-103.

[2]车小磊, 张金生.凝心聚力务实进取全力推动水库移民和水利扶贫工作新 发展——访水利部水库移民司司长卢胜芳[J].中国水利,2019,23(24):25-26+29.

[3] 陈波, 李啸. Office联动及宏在水库移民搬迁协议系统中的应用 [J]. 人民长江,2019,50(S2):226-228+242.

[4]李芳.大中型水库移民动迁补偿资金使用管理存在问题及对策探 析[J].地下水,2019,41(06):246-247. 


\section{2 毫州水环境质量改善阶段性成果}

2.1 “水活” 目标初步实现

近几年, 毫州城区实施 “水活” 工程, 对原有的河道进行综合治理, 利 用浴河大寺闸上下游的水位差和自然坡降, 自宋汤河小洋桥闸引浴河水, 已实现了浴河 $\rightarrow$ 宋汤河 $\rightarrow$ 凤尾沟 $\rightarrow$ 毫城河 $\rightarrow$ 赵王河水系、浴河 $\rightarrow$ 宋汤河 $\rightarrow$ 凤尾沟 $\rightarrow$ 龙凤新河 $\rightarrow$ 赵王河水系、浴河 $\rightarrow$ 宋汤河 $\rightarrow$ 张河 $\rightarrow$ 赵王河水系、浴 河 $\rightarrow$ 宋汤河 $\rightarrow$ 赵王河水系等输水线路贯通, 毫州城区浴河以南水系初步实 现 “水活”目标。

\section{2 分级换水改善城区水质}

“一涵四闸”等水系贯通控制工程的顺利建成, 实现了毫州城区主要 水系整体分区分流调控、分级分流控制, 促进河道水体自然调节流动, 实现 主要水系逐段逐级分流换水, 增强河道水体自主净化能力, 改善了宋汤河、 凤尾沟、龙凤新河等城区主要河道整体水质。

2.3 社会经济效益显著

“水活”工程的稳步实施, 塑造了当地水景观、改善了当地水资源环 境、展现了当地水文化, 为当地市民提供了一个休闲娱乐、锻炼的好地方, 对吸引更多的外地人士来到毫州市安居、创业、投资、旅游等发挥了极大 的作用。2016年1月1日, 安徽省委书记李锦斌同志参观调研 “水活” 工程 一毫菊路钢坝闸时, 对项目取得的成效给予了充分肯定, 并指出 “水活” 项 目的实施, 把毫州的历史文化与绿色发展理念融合了起来, 畅通了城市水 系, 改善了水质, 不仅城市环境得到治理, 城市文化品位也得以提升。2019 年6月8日, 台湾新竹农田水利会来毫州市考察交流毫州城区水系治理工作 时, 对我市城区水系建设的科学规划、工程设施、建设成效给予了高度赞 赏, 并表示其通过考察活动, 汲取了毫州市治水的宝贵经验, 此次会面有效 的推动了海峡两岸水利事业的共同发展。

\section{3 毫州改善水环境工作目前存在的不足}

3.1 “水活” 工程的建设仍然任重道远

目前, 城区 “水活”工程的实施, 只有浴河以南水系初步实现了 “水活” 目标, 铁路以东水系如毫城新河等河道尚未治理, 窑鸿沟、窑鸿支沟水系还 未深度治理, 一些涵闸控制工程还需要新建和维修加固。水系贯通规划修 编后, 还要增加黑风沟、浴包河等一些水系贯通治理和洜站提水工程的内 容, 整体 “水活”工程的建设任务还相当复杂艰巨。

3.2 “水活”工程的治污方面还存在着较大的局限性

“水活”工程的实施可以通过水系贯通和涵闸控制工程调度实现换水, 从而在一定程度上改善水质, 但治标不治本。河流污染的主要原因是沿河 截污工作不彻底, 遇大雨时、大量污水随雨水直排河道, 严重污染水体。相 关部门既要解决城区水污染排放问题, 还要督控让排污企业彻底排污治污, 沿河彻底截污, 雨污处理管网彻底清淤。

\section{4 全面提升毫州水环境建设的对策建议}

4. 1 完善 “水活” 工程建设
市水利局按照市委、市政府年度计划安排, 根据《毫州市中心城区水 系贯通规划方案》逐步推进毫城新河 (养生大道一高速路口) 综合治理工程 的前期工作。因城区规划面积从原来的 $140 \mathrm{~km}^{2}$ 扩大到现在的 $218 \mathrm{~km}^{2}$, 市水利 局及时对《毫州市中心城区水系贯通规划方案》进行了修编, 逐步对北城 区、西城区、东城区的 “水活” 工程进行补充和完善; 加快推进宋汤河六 期、窑鸿沟及窑鸿支沟工程建设; 启动实施 “一涵三闸” 水系贯通控制工 程(窑鸿沟养生大道涵、窑鸿沟蓄薇路闸、毫城新河十九里闸、毫城新河 蒋庄闸）。

4. 2 优化水质改善体系 促进水资源可持续利用

水利部门密切高度关注宋汤河、凤尾沟、龙凤新河等主要河道整体水 质变化情况, 及时组织调度 “一涵四闸” 等河道涵闸控制工程, 对城区河道 主要水体进行逐段逐级清理换水, 有效控制改善城区河道整体水质。水利 部门计划明后两年, 对毫城新河等工程重点进行集中综合治理, 全面实现 城区水系全线贯通, 最终实现 “水清、岸绿、景美、河畅” 的集中治理工 程目标。

4. 3 提高城市民众保护水资源环境意识

一些重工业企业快速发展的同时忽视了机器生产带来的城市水资源 环境污染问题, 再加上部分城市民众保护水资源环境的意识不强, 往河道 里乱扔乱丢生活垃圾的行为严重破坏了城市水资源环境。上述行为使得我 国城市生活水体污染的情况呈不断加重的恶化趋势。另外, 社会上对于水 资源环境污染源的防治、保护水资源环境的相关工作关注、支持力度不够。 以上种种原因导致毫州市城区水资源环境污染源多样, 毫州市城区水资源 污染的防治工作与城市水资源环境保护工作的难度不断加大。政府及水利 部门要把 “预防为主、防治结合” 作为综合治理城市水资源环境污染问题 的重要手段, 紧抓城市生活污水与其他工业污水的污染源头, 提高大部分 民众保护城市水资源环境的意识, 这样也就可以从根本上有效杜绝各类污 染城市水资源环境的现象频繁发生。

\section{5 结束语}

综上所述, 毫州市水利部门有效地改善了本市水资源生态环境, 为广 大市民营造了更加舒适、优美、宜居的城市居住环境, 提升了毫州市的文 化品位。龙凤公园、望月潭公园等一些水体公园成为市民主要的户外游憩 景点, 城区水系贯通河道综合治理工作的成效显著, 基本达到预期的治理 效果。

\section{[参考文献]}

[1]郑苗苗.关于市政水环境综合整治的思考[J].建材与装饰,2020,(7):166-167.

[2] 孔祥文.城市水环境智慧水务系统建设探索 [J]. 环境与发 展,2020,32(02):239-240.

[3]孙威,孙源.浅析城市水环境修复技术[J].低碳世界,2020,10(1):3-5.

[4]蔡奇.构建水系治理长效机制全面提升首都水环境建设水平 $[J]$. 河 北水利,2017,(03):8+27. 